\title{
Cradle-to-gate life cycle assessment of beneficiated phosphate rock production in Tunisia
}

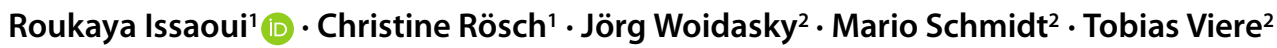 \\ Received: 30 March 2021 / Revised: 28 October 2021 / Accepted: 3 November 2021 / Published online: 21 January 2022 \\ (c) The Author(s) 2022
}

\begin{abstract}
To improve the sustainable management of phosphorus, numerous LCA studies, using primary data, have been conducted for phosphorus recovery technologies from wastewater, but not for phosphate rock mining.

This article addresses this issue by conducting a cradle to gate assessment of beneficiated phosphate rock production using primary data. This study aims to share an updated Life Cycle Inventory dataset of beneficiated phosphate rock production. The studied system is the open-pit mining operations and the wet beneficiation process located in the south of Tunisia. The functional unit is $1 \mathrm{~kg}$ of $\mathrm{P}_{2} \mathrm{O}_{5}$. Twelve environmental impact categories were assessed using the ReCiPe Midpoint method. The results of Life Cycle Inventory show that the average loss of phosphorus between mining operations, mechanical preparation, and the wet beneficiation is $0.3 \mathrm{~kg}$ of $\mathrm{P}_{2} \mathrm{O}_{5}$ per $1 \mathrm{~kg} \mathrm{P}_{2} \mathrm{O}_{5}$. The losses occur mainly during the scrubbing and hydrocycloning. Compared to the production system in Florida, USA, according to the Ecoinvent database 3.4, the production of $1 \mathrm{~kg} \mathrm{P}_{2} \mathrm{O}_{5}$ in Tunisia has higher Global Warming Potenzial, higher water depletion potential, higher PM10 emission, Photochemical oxidant formation, soil pollution potential, and human toxicity potential.

In conclusion, primary data shows comparable results to the generic Life cycle Inventory of wet beneficiation phosphate rock in the Ecoinvent database. This study contributes to enlarge data about sedimentary phosphate rock extraction and beneficiation globally as currently only the USA and Morocco were reported in databases.
\end{abstract}

Keywords Life Cycle Assessment · Phosphate rock mining · Life Cycle Inventory · Environmental impacts

\section{Ökobilanz der Produktion von aufbereitetem Phosphatgestein in Tunesien (von der Wiege bis zu Bahre)}

Availability of data and material Primary data are made available by the company CPG for the authors in form of paper documents. The documents are confidential and any further access has to be approved by the company. Only the relevant data for the study is allowed to be used and stocked by the authors. The documents remain the property of the company.

Code availability Not applicable

Roukaya Issaoui

roukaya.issaoui@partner.kit.edu

1 Institut für Technikfolgenabschätzung und Systemanalyse (ITAS)/Karlsruhe Institut für Technologie (KIT), Karlsruhe, Germany

2 Institut for Industrial Ecology (INEC)/Hochschule Pforzheim, Pforzheim, Germany

\section{Introduction}

According to the European commission's studies, phosphorus is classified as a critical raw material for European industries and emerging technologies (European Commission 2010, 2017, 2020c; EU Ad-Hoc Working Group on Raw Materials 2014).

The European Commission called to take action towards the sustainable supply of criticical raw materials by reducing dependency on primary critical raw materials and dependency on emerging countries through the circular use of resources, sustainable products, and innovation (European Commission 2020a). One of the actions toward reducing dependency on primary critical raw materials from emerging countries is diversifying supply from primary and secondary sources and improving resource efficiency and their circularity (European Commission 2020b). The integration of 
the secondary source of phosphorus has to go hand in hand with the phosphorus's primary source's sustainable production and use of phosphate rock. Moreover, the global phosphate rock reserves are highly geo-concentrated, mainly in North Africa (Morroco 50 Gt (USGS National Minerals Information Center 2019), Tunisia 3.3 Gt (Mining planification direction 2018), and Algeria 2.2 Gt (USGS National Minerals Information Center 2019)), which control $76 \%$ of the global reserves. In this context, this research aims to bring insights into phosphate rock production conditions in Tunisia, one of the global leaders of phosphate rock production. The country's choice was made based on the applied open-pit mining technique, which is widely used to produce sedimentary phosphate rock (Van Kauwenbergh 2010), and the easy access to the data from the company $\mathrm{CPG}^{1}$ an industrial partner of the research work. ${ }^{2}$

\section{Research gap}

Due to the lack of reporting on the phosphate rock supply chain, there are four areas of weak and incomplete reporting information (Nedelciu et al. 2019):

- phosphate rock reserves and resources

- losses along the supply chain

- environmental and socio-political externalities of phosphate mining

- and the access to data

To this end, this paper aims to provide primary data on the environmental impacts of open-pit mining and wet beneficiation of phosphate rock. Circularity of phosphorus including its recycling etc. are therefore not within the scope of this research.

\section{Method}

\subsection{Goal and scope}

This study is part of larger doctoral research project, where the results of this assessment are intended to be used for the discussion of the interconnection between environmental

\footnotetext{
1 CPG: Companie des Phosphates de Gafsa, is a state-owned enterprise It ranks 5th among ten largest producers of beneficiated phosphate rock worldwide in 2010 with an annual production of $8 \mathrm{Mt}$ before the drop of the production in 2011 (2.2 Mt) due to socio-political instability. In 2017, the company produced 3.9 Mt of beneficiated phosphate rock.

2 This paper is part of a Ph.D. work. The thesis investigates the interrelation between environmental impacts and social impacts of the phosphate mining sector in producing countries and their potential implications in the country's socio-political stability to mitigate the risk of phosphate criticality on the global market.
}

impacts and social impacts of phosphate rock mining and beneficiation in local conditions in Tunisia. The goals of this study are:

1. to identify the key environmental performance of beneficiated phosphate rock and to determine the environmental weak spots of the production system in Tunisia.

2. to provide primary data and to develop respective life cycle inventory datasets based on field trips and data provision from mining sites and beneficiation plants in Tunisia to contribute to future LCA studies that include phosphorus use.

3. to compare the results to existing life cycle inventory studies on phosphorus (Primas et al. 2007) used in the Ecoinvent database.

The studied system is the open-pit mining and wet beneficiation of phosphate rock in the region of Gafsa southwest of Tunisia. The considered product system is the production of beneficiated phosphate rock from cradle-to-gate (see Fig. 1). The analysis's scope refers to an average production capacity of 5 million metric tons (Mt) of beneficiated phosphate rock per year.

\subsection{Functional unit and system boundaries}

The functional unit is $1 \mathrm{~kg}$ of Phosphorus Pentoxide $\left(\mathrm{P}_{2} \mathrm{O}_{5}\right)$ generally used to express the phosphorus content in the commercial fertilizers, phosphoric acid and the commercial beneficiated phosphate rock. The $\mathrm{P}_{2} \mathrm{O}_{5}$ content reflect the functionality and the technical specifications and standards of the product especially when it comes to plant nutrition from fertilizers as phytoavailable phosphorus in soil is expressed in $\mathrm{P}_{2} \mathrm{O}_{5} \mathrm{mg} / \mathrm{kg}$ soil. Besides, the geological grade of phosphate rock refers to the $\mathrm{P}_{2} \mathrm{O}_{5}$ content of the crude ore.

Twelve environmental impact categories were assessed using the ReCiPe Midpoint method (Goedkoop et al. 2009). The ReCiPe method has three characterization scenarios or perspectives defined according to the different sources of uncertainty and the different choices and assumptions. For this work, the hierarchist perspective $(\mathrm{H})$ was used as it is considered to be the default model, and a consensus model often used in scientific modeling (PRé Sustainability 2020). The Hierarchist perspective has a longer time horizon for the environmental mechanism as the individualist perspective. For instance, the time horizon perspective for the environmental mechanism of climate change is 100 years in the Hierarchist perspective and 20 years in the individualist perspective.

The study was conducted on the OpenLCA software v.10. The data selected for a site-specific assessment type "cradle to gate" were collected from the nine active Tunisian mining sites for the mining operations and 


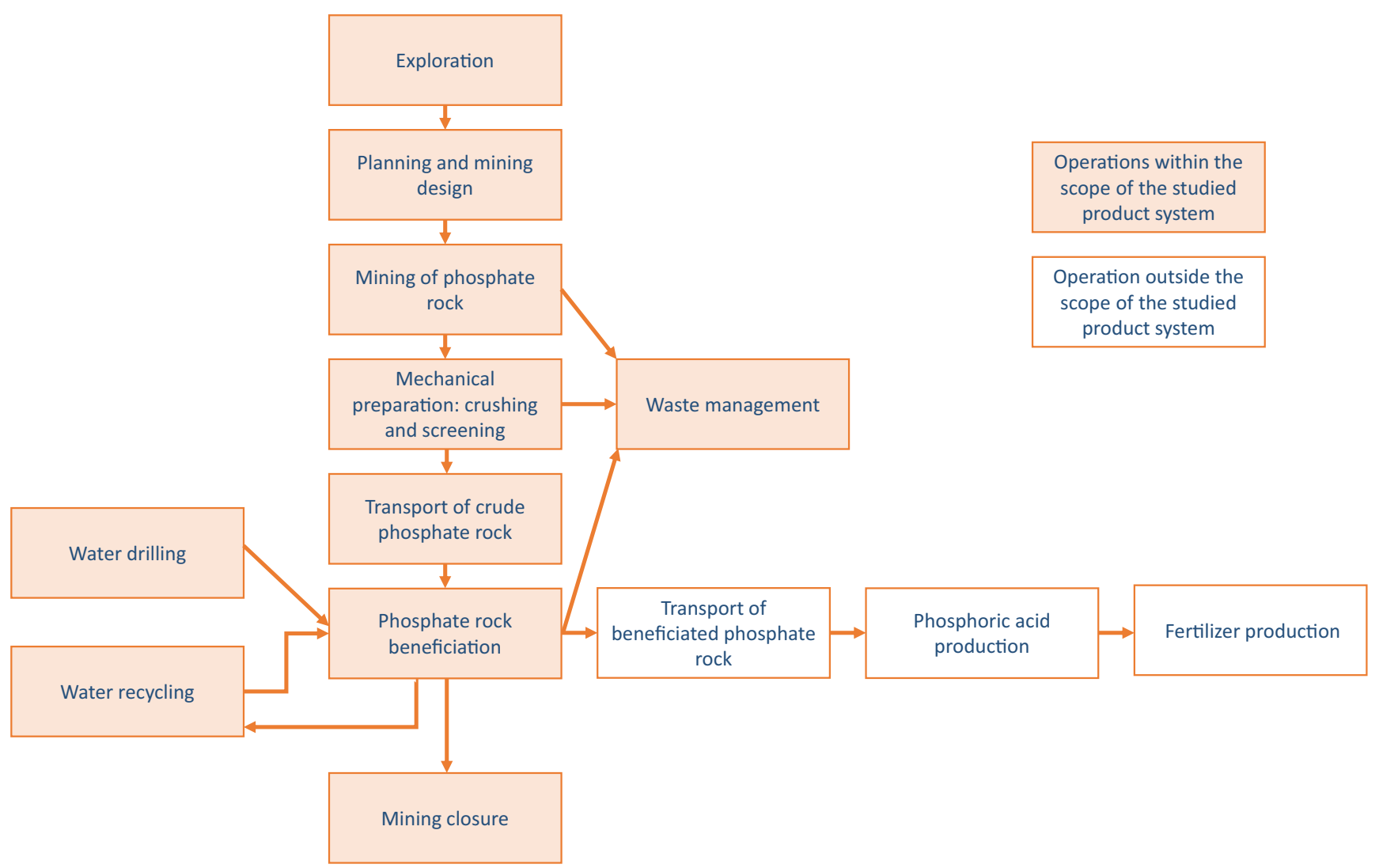

Fig. 1 Product system and the system boundaries of the environmental life cycle assessment

from ten washing plants for the wet beneficiation process. All the processs and flows relevant to the studied system are included in the system boundaries. The cut-off criteria applied to the calculation is $1 \%$ assuming that not relevant activity such as office activites like accounting, marketing and administration have contribution.

The mineralogical composition of the Gafsa basin phosphate is heterogeneous, with quantitative variations of the $\mathrm{P}_{2} \mathrm{O}_{5}$ content, $\mathrm{Cd}$ and others chemical elements between the mining sites and also between different layers in the same site. For this study, the crude phosphate rock's average content is $24 \% \mathrm{P}_{2} \mathrm{O}_{5}$, and the average content of the beneficiated phosphate rock is $29 \% \mathrm{P}_{2} \mathrm{O}_{5}$. Table 1 shows the average chemical properties of Tunisian beneficiated phosphate rock.

\subsection{Life cycle inventory (LCI)}

\subsubsection{Type and source of data}

The collected data are inputs such as chemicals, electricity, water, fuel, phosphate rock, and machinery. The emissions were calculated based on emission factors taken from literature. The collected data are for 2016 and 2017. The data sources are the company's official reports and the mate- rial balance reports of washing plants and mining sites and previous research projects at the CPG research center. For the background processes ${ }^{3}$, generic data were used from the "Ecoinvent" database Version 3.4.

\subsubsection{Process description}

The phosphate rock is mined in an open-pit site. In the Gafsa phosphate rock deposit, there are eight layers of phosphate rock. The overburden limestone is very thick, and its average height is $45 \mathrm{~m}$ (it varies between $20-60 \mathrm{~m}$ ). The intermediate layers vary between $50 \mathrm{~cm}$ and $4.5 \mathrm{~m}$.

The strip ratio- the total $\mathrm{kg}$ moved rock per $\mathrm{kg}$ crude phosphate rock ( $40 \mathrm{~mm}$ size $)$ - was 13:1 in 2016 ( $1 \mathrm{~kg}$ crude ore contains an average of $24 \% \mathrm{P}_{2} \mathrm{O}_{5}$ ). The strip ratio varies from 8 to 15 in the Gafsa mining basin. In comparison to other phosphate rock mining process such as Morocco, where the strip ratio varies between $3.5: 1$ and $8: 1(1 \mathrm{~kg}$ crude ore contains $27 \% \mathrm{P}_{2} \mathrm{O}_{5}$ ), and the USA, where the average strip ratio is $2.4: 1$ ( $1 \mathrm{~kg}$ crude ore contains $9 \%$

\footnotetext{
3 The background system consists of processes on which no or, at best, indirect influence may be exercised by the decision-maker for which an LCA is carried out. Such processes are called "background processes." [81].
} 
Table 1 Chemical properties of beneficiated phosphate rock in Tunisia according to the chemical analysis at the CPG

\begin{tabular}{llll}
\hline Element & Unit & Average Value & $\mathrm{CV}^{\mathrm{a}}$ \\
\hline Phosphorus as $\mathrm{P}_{2} \mathrm{O}_{5}$ & $\%$ & 29 & $2 \%$ \\
Calcium Oxide $\mathrm{CaO}$ & $\%$ & 48.33 & $1 \%$ \\
Fluorine & $\%$ & 3.7 & - \\
Magnesium Oxide $\mathrm{MgO}$ & $\%$ & 0.52 & $14 \%$ \\
Carbon organic $_{\text {Cadmium Cd }}$ & $\%$ & 0.75 & $24 \%$ \\
Uranium $^{c} \mathrm{U}$ & $\mathrm{ppm}$ & 35 & $36 \%$ \\
Thorium $^{c} \mathrm{Th}$ & $\mathrm{ppm}$ & 46.5 & - \\
\hline
\end{tabular}

The average of 9 mining sites (the value can change for one mining site as the sample composition from different layers can change)

${ }^{\mathrm{b}}$ The coefficient of variation

${ }^{c}$ The value of $U$ and $T h$ are taken from the doctoral work on the radioactive element in Gafsa phosphate at the CPG [78]

$\mathrm{P}_{2} \mathrm{O}_{5}$ ) as $4.5 \mathrm{~kg}$ crude ore is needed for $1 \mathrm{~kg}$ beneficiated phosphate rock and for every $1 \mathrm{~kg}$ beneficiated rock $11 \mathrm{~kg}$ total soil has to be moved (Primas et al. 2007).

The process of phosphate production in Tunisia comprises mainly mechanical steps with different equipment for mining, transportation, and screening and crushing. A simplified process flow of phosphate rock mining operations and the industrial process of the wet beneficiation at $\mathrm{CPG}$ is shown in Fig. 2. A detailed description of the process is available in the supplement document.

The functional unit $1 \mathrm{~kg} \mathrm{P}_{2} \mathrm{O}_{5}$ is equivalent to $3.45 \mathrm{~kg}$ of beneficiated phosphate rock $\left(29 \% \mathrm{P}_{2} \mathrm{O}_{5}\right)$ and $4.17 \mathrm{~kg}$ of crude phosphate rock ${ }^{4}\left(24 \% \mathrm{P}_{2} \mathrm{O}_{5}\right)$ as visualized in Fig. 4. However, it needs $5.32 \mathrm{~kg}$ of crude phosphate rock of

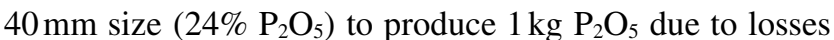
during the mechanical preparation. During the crushing and screening, the backfilled rocks with a size between $>40-<120 \mathrm{~mm}$ contain an average of $6 \%$ crude phosphate rock and it can be used in the future. Moreover, around $10 \%$ of crude phosphate rock is lost during the first screening operation (at $60 \mathrm{~mm}$ ), and an additional $10 \%$ of crude phosphate rock is lost during the second screening (at $40 \mathrm{~mm})$.

After the mechanical preparation, the crude phosphate rock is transported to the beneficiation plant where it will be mixed with water and undergoes operations of screening, classification, and filtration to remove impurities and coarse and produce a concentrate of phosphate rock containing $29 \%$ of $\mathrm{P}_{2} \mathrm{O}_{5}$.

Losses also occur during wet beneficiation, the coarse rejects are sent to the stockpile, containing $10-15 \% \quad \mathrm{P}_{2} \mathrm{O}_{5}$. The average loss of phosphorus between mining operationsmechanical preparation and the wet beneficiation process is

\footnotetext{
${ }^{4}$ It refers to the phosphate rock after the crushing and screening to
} $0-40 \mathrm{~mm}$ and before the wet beneficiation.
$0.3 \mathrm{~kg}$ per $\mathrm{kg} \mathrm{P}_{2} \mathrm{O}_{5}$ (see Fig. 3). A similar value of $31 \%$ losses per $\mathrm{kg} \mathrm{P}_{2} \mathrm{O}_{5}$ in Florida and Carolina in the USA was reported by (Primas et al. 2007) based on the work of (Jasinski and Lindsay 2001).

The last step of the process is the dewatering of the phosphate rock slime and water recycling at the wastewater treatment plant. After a decantation and flocculation of the slurry, around $55 \%$ of the water is reused in the washing process the concentrated slime or tailing (the range of wt. solid concentration is $126-200 \mathrm{~g} / \mathrm{l}$ ) is discharged into a settling pond outside the plant where the water will be evaporated.

\subsubsection{Process inputs}

The primary operative resources for the inventory of the process "Mining operations phosphate rock" are the natural resources from the ground, the machinery to perform the extraction and the transport, the mining infrastructure, nitrate explosives, and the energy (Diesel and electricity). The operative resources for the inventory of "Wet beneficiation phosphate rock" are the crude phosphate rock (the output of the Mining operations process), water, chemicals, infrastructure and machinery, and energy (mainly electricity). The detailes inputs per functional unit of $1 \mathrm{~kg} \mathrm{P}_{2} \mathrm{O}_{5}$ are displayed in Table 1 in the Supplement. For the process flow "Occupation mineral site", the average total occupied area per year is $1.2 \mathrm{~km}^{2}$ to extract $4082 \mathrm{~kg}$ of crude phosphate rock per $\mathrm{m}^{2}$. The overburdens are stockpiled in an area that covers $50-60 \%$ of the total occupied area. The average occupation period is considered 20 years. For the process flow "land transformation", the area used is around $200 \mathrm{~km}^{2}$. The transformation of the land from desert to mineral extraction area is selected. After the mining site's reclamation, the overburden and settling ponds are considered future phosphate reserves as they contain 2 to $15 \%$ of $\mathrm{P}_{2} \mathrm{O}_{5}$ which is currently not economically feasible to recover. Therefore, it is considered a land transformation back to the mineral extraction area. The mining operations, such as drilling and excavation, use diesel driven engines. Trucks of 85 metric tons are used for the transport of phosphate rock, and Dumpers are used to transport the overburden. Electrical energy from the national grid is used for the crushing and screening and the transport by conveyor. The conveyor is used only if the distance between the crushing unit and the washing plants is not superior to $10 \mathrm{~km}$. The mining operations require an average of $0.174 \mathrm{MJ}$ final energy per $\mathrm{kg}$ of crude phosphate rock $\left(0.725 \mathrm{MJ}\right.$ per $\left.\mathrm{kg} \mathrm{P}_{2} \mathrm{O}_{5}\right)$ as diesel burned in the machinery. The electricity used during the mining operations is marginal (5.95E-04 MJ per kg of crude phosphate rock and 2.5E-03 MJ per $\mathrm{kg}_{2} \mathrm{O}_{5}$ ). The explosive used in the blasting step is a mixture of Ammonium Nitrate 


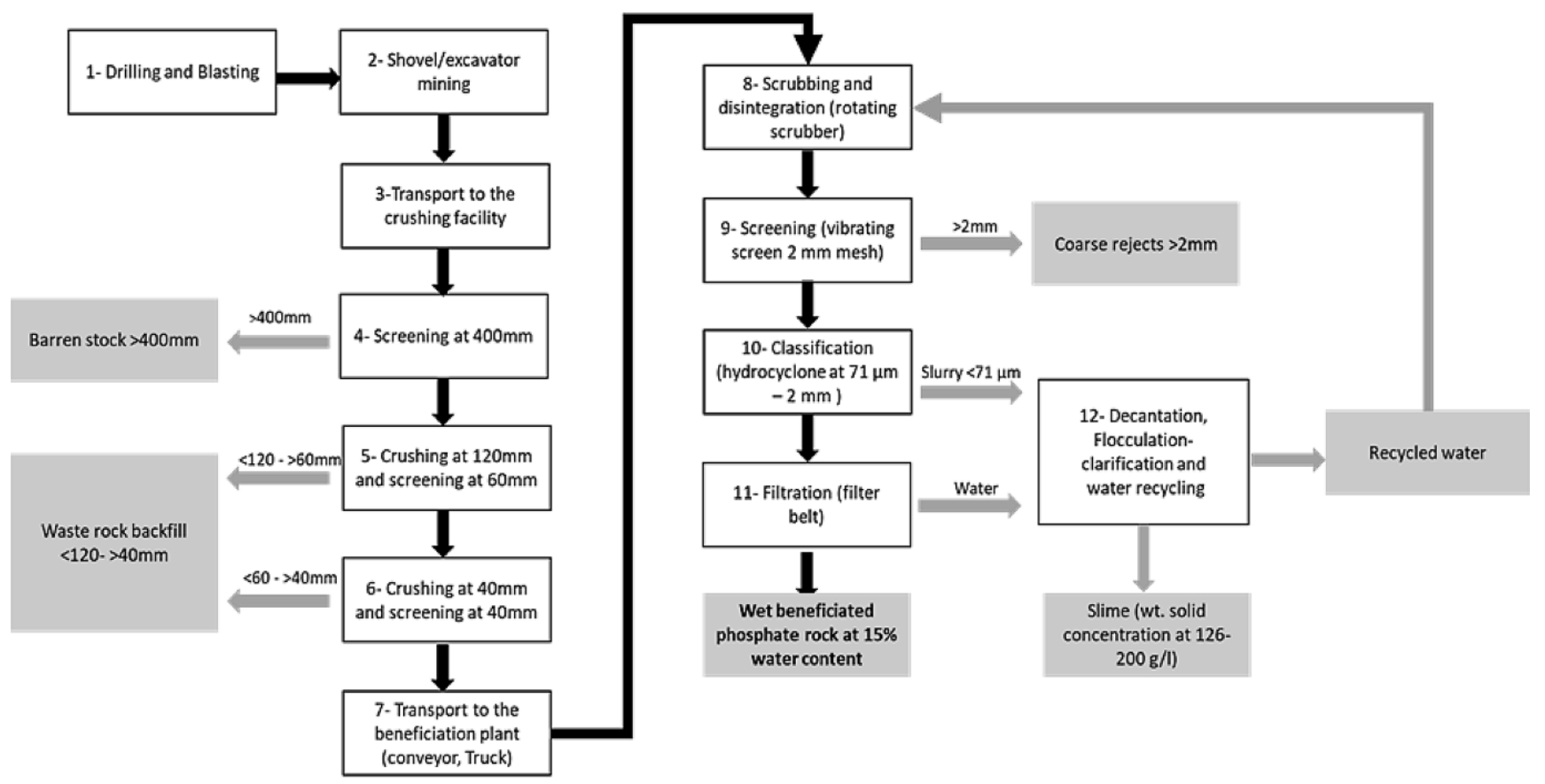

Output of the process

Fig. 2 Simplified process of phosphate rock mining operations and the industrial wet beneficiation process at CPG, Tunisia
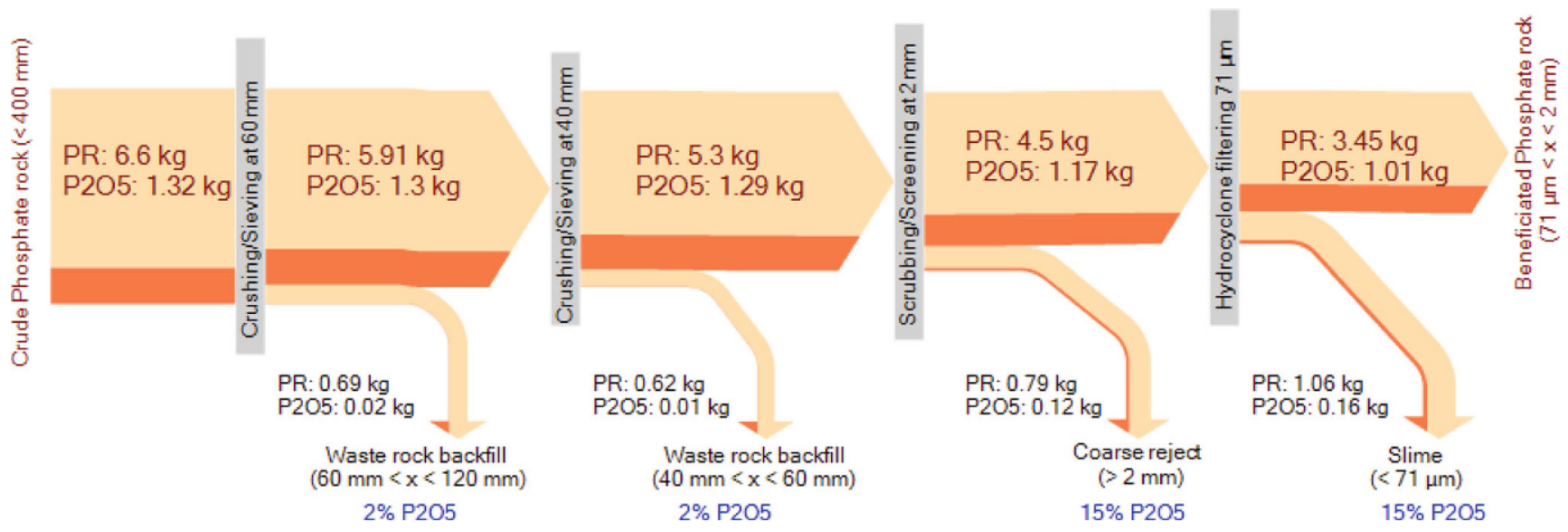

Flow of PR: phosphate rock

Flow of $\mathrm{P}_{2} \mathrm{O}_{5}$

Fig. 3 Sankey flow diagram of phosphate rock (in beige) and $\mathrm{P}_{2} \mathrm{O}_{5}$ (in orange) during mining operations and wet beneficiation per functional unit of $1 \mathrm{~kg} \mathrm{P} \mathrm{P}_{2} \mathrm{O}_{5}$

fuel (ANFO) and Nitrate explosive mentioned as N30 in the mining sites' reports.

In contrast to mining operations, the beneficiation process uses more electric energy than diesel. The scrubber, the vibrating screen, the hydro-cyclone, and the filtration use electric energy. The total consumption of washing, screening, and flocculation is $0.041 \mathrm{MJ}$ of electric energy and $0.0036 \mathrm{MJ}$ of diesel per $\mathrm{kg}$ of beneficiated phosphate rock at $29 \% \mathrm{P}_{2} \mathrm{O}_{5}$. The final energy consumption of the beneficiation process is $0.045 \mathrm{MJ}$ per $\mathrm{kg}$ beneficiated phosphate rock at $29 \% \mathrm{P}_{2} \mathrm{O}_{5}$ and $0.15 \mathrm{MJ}$ per kg of $\mathrm{P}_{2} \mathrm{O}_{5}$. As the water is drilled groundwater, for this inventory, the process flow is "Water well in the ground." Water loss occurs during the transfer from the drilling station to the beneficiation plants. It is estimated to be $10-12 \%$ of the total annual groundwater drilled by the company. For this inventory, $10 \%$ of 
industrial water was added on top of the annual industrial water consumption of the CPG. The flocculant used for water clarification from the slurry is "Slime floc 150", an anionic polyacrylamide.

\subsubsection{Process emissions}

For the inventory of mining operations, only the emissions to air were considered, because the mining operations in Tunisia are conducted dry and there are no large water bodies located directly or near the mining sites. The backfill of the overburden and intermediate layers are not considered waste, as they are returned back to the ground.

For the blasting operation, a flow process was attributed named "Blasting phosphate-TN" (see Supplementary Material Appendix 2, Table 2). The emissions of blasting into the air were assumed to be mainly Carbon Monoxide (CO) and Nitrogen Oxides (NOx). The calculation is based on the data found in the literature on the behavior of different Nitrate explosives (Bronzo Perasso-carrière et bétons 2018; Organisme Professionnel de Prévention du Bâtiment et des Travaux Public 2003). The volume of the Carbon Monoxide and Nitrogen oxides are estimated to be $\mathrm{CO}+5 \mathrm{NOx}$ $1 / \mathrm{kg}$ of explosive (Organisme Professionnel de Prévention du Bâtiment et des Travaux Public 2003). In addition to the toxic gases, dust and particulate matter (PM) are released into the air during blasting. An average dust ratio of $2 \mathrm{~g} / \mathrm{m}^{3}$ of gas emitted can be retained (Bronzo Perasso-carrière et bétons 2018).

For this inventory, the emission of Particulate matter (PM) was calculated according to the method of the European Environment Agency (EEA) using their spreadsheet model, which was developed and made available by the EEA to calculate particulate emissions at the country level for "Quarrying and mining of minerals, other than coal" (European Environmental Agency 2019a). The EEA method consists of modeling the individual mining process steps using regional data and the studied mineral production sites' data. Dust emissions in quarries come from multiple points (Drilling and Blasting, Material processing, Internal transport on the unpaved road, loading and unloading, wind erosion from stockpile). They are distributed within a vast area, which could have different wind and precipitation properties (European Environmental Agency 2019b). The emission factor of removing the overburden by bulldozer and excavator shovel is $698 \mathrm{~g} \mathrm{PM} /$ metric ton of crude phosphate rock (Tartakovsky et al. 2016). The data was taken from the study of Tartakovsky et al. (2016) for the mining area in the desert of Syria, which have a comparable weather condition to Gafsa mining area. For the regional data, the meteorological data of the different cities nearby the mining area were used, which are: Gafsa south district, Metlaoui, Redeyef, Moulares, and M'dhila (Weatherspark
2020). The wind erosion from stockpiles was not included as an emission point due to missing data about the number of stockpiles and the stockpiles' average time on the storage area. Internal transport (transport of phosphate rock and waste between different sites) has a very high emission factor of dust since $96 \%$ of the internal transportation occur on an unpaved road (see Table 4 in the Supplement).

For the emission of radioactive element to the air, it is generally assumed that dust particles emitted have the same specific activity as the phosphate rock (U.S. Environmental Protection Agency 1998). Therefore, the emission of radioactive elements to the air was estimated by multiplying the phosphate rock's specific activity with the total suspended particles (TSP). The data about the specific radioactive activity of phosphate rock was taken from the work of Fattah (2005) at the research center of the CPG, analyzing samples from four deposits at the CPG (Fattah 2005) and from the work of Khelifi (2012), analyzing samples from the phosphate deposit of Om Lakhchab at the CPG (Khelifi 2012). The radionuclides which were subject to the mentioned studies are the Uranium-238 $\left({ }^{238} \mathrm{U}\right)$, the Thorium-232 $\left({ }^{232} \mathrm{Th}\right)$, the Radium-226 ( $\left.{ }^{226} \mathrm{Ra}\right)$, and the Potassium-40 $\left({ }^{40} \mathrm{~K}\right)$. For this inventory, the air emissions were calculated for a low-density population. The emission of cadmium $(\mathrm{Cd})$ to the air during "Mining operations phosphate rock" is calculated by multiplying the average content of crude phosphate rock, which is $36.7 \mathrm{ppm}$ (according to the analysis of 2017) by the emission factor of TSP (Total suspended Particles).

The outputs of the process, "Wet beneficiation phosphate rock" are emissions to water and to soil. It does not produce emission to air (the machinery at the beneficiation plant use electric energy). The water emissions are mainly sulfate, phosphorus, and fluorine due to the leaching of those elements from the solid fraction of the slurry (slime) into the water fraction (wastewater). The routes of contamination of water by phosphorus, sulfate, and fluorine are mainly (1) the leakage of the canal during the transfer of the slurry from the beneficiation plant to the settling ponds, (2) the leakage of the settling ponds, and (3) the contamination of municipal canalization by the beneficiated phosphate rock lost from the trucks during the road transport. In 2016, 1205 metric tons of beneficiated phosphate rock were lost during road transport, and six metric tons were lost in 2017 (Direction of Accounting 2017, 2018). In order to calculate the emission to water and soil, data on the slurry's chemical analysis were taken from the work of Smida at the CPG (Smida 2012). For this inventory, the concentrations of phosphorus, sulfate, and fluorine were multiplied by the volume of the liquid wastewater fraction of the slurry. The soil contamination comes mostly from the infiltration and accumulation of heavy metals from the settling ponds to the surrounding soil. The emissions of heavy metals to the soil 
were calculted by multipliying the concentration of heavy metal in the slurry with the amount of slime. All the detailed emissions per functional unit of $1 \mathrm{~kg} \mathrm{P}_{2} \mathrm{O}_{5}$ are displayed in Table 3 in the supplement.

\section{Environmental impact assessment}

Table 2 summarizes the environmental impacts in all chosen $\mathrm{ReCiPe}$ impact categories for producing $1 \mathrm{~kg} \mathrm{P}_{2} \mathrm{O}_{5}$. In absolute terms the environmental hotspots located in the Gafsa region concern water-related issues such as water depletion (12 $\mathrm{Mm}^{3}$ per year) and water pollution (92 metric tons $1,4 \mathrm{DB}$ eq and 54 metric tons of $\mathrm{P}$ were released into the water), soil-related problems (terrestrial acidification of 135,418 metric tons of $\mathrm{SO}_{2}$ eq per year), and human health related environmental impacts including photochemical oxidant formation $\left(242,750\right.$ metric tons of NMVOCs per year ${ }^{5}$, climate change (134,415 metric tons of $\mathrm{CO}_{2}$ eq per year), and human toxicity $(87,209$ metric tons of $1,4 \mathrm{DB}$ eq per year)).

Both mining operations and the wet beneficiation process have direct impacts. The process "Mining operations" has direct emission to air, soil and contributes to damage the human health with the emission of radioactive elements, cadmium, dust during blasting and mechanical preparation, and direct emission of GHGs due to high use of diesel. The process "Wet beneficiation phosphate rock" has direct emissions to water such as fluorine, cadmium, zinc, sulfate, and phosphorus. Besides, the results show that the beneficiation of phosphate rock directly impacts water depletion with a contribution of $0.012 \mathrm{~m}^{3} / \mathrm{kg} \mathrm{P}_{2} \mathrm{O}_{5}$.

5 The average of 2016-2017: the production of beneficiated phosphate rock was respectively $3.4 \mathrm{Mt}$ and $3.9 \mathrm{Mt}$, the average production used for the calculation is $3.5 \mathrm{Mt}$.

\section{Discussion}

\subsection{Result interpretations}

Our assessment shows that producing beneficiated phosphate rock in Tunisia has a large range of environmental impacts. The reduciton of losses is one option to reduce such impacts. Currently, the product system in Tunisia has an average loss of $0.3 \mathrm{~kg}_{2} \mathrm{O}_{5}$ per $1 \mathrm{~kg} \mathrm{P}_{2} \mathrm{O}_{5}$ during mining operations and the beneficiation according to the actual beneficiation rate $(65 \%)$. The efficiency could be improved at the beneficiation process as losses of phosphate occur during the scrubbing and hydro-cyloning, and filtering and due to the absence of the flotation process to recover the phosphate particle lost in the slurry.

The mining operations are the main contributor to human health damage (dust emission, radioactivity, photochemical oxidant, GHGs, and cadmium) and soil acidification due to nitrate explosives (see Fig. 4). Besides, the emission to air during blasting, the dry mechanical preparation, and the transport on unpaved rock release dust charged with radioactive elements and cadmium into the air, which can lead not only to air pollution but also to a high potential of soil contamination. For instance, the existence of potential transfer of radioactive elements between the air and soil due to phosphate rock mining was a subject of a study about the natural radioactivity of the Gafsa soil in 1991 (Charni Majoubi et al. 1991). Due to the arid and dry climate in the region, the dust emitted by the mining activities and containing polluting elements is carried out by the wind to the surrounding areas (Charni Majoubi et al. 1991). Their study shows that the soil radioactivity in $\mathrm{Ra}$ and $\mathrm{U}$ increases as it gets closer to mine sites.

The wet beneficiation process directly impacts water depletion, water eutrophication, and soil and water ecotoxicity. The difference in water consumption is explained as the

Table 2 Impact assessment results of producing $1 \mathrm{~kg} \mathrm{P}_{2} \mathrm{O}_{5}$ by stage and their direct impact

\begin{tabular}{|c|c|c|c|c|c|c|}
\hline \multirow[t]{2}{*}{ Impact category } & \multirow[t]{2}{*}{ Unit } & \multicolumn{2}{|c|}{ Mining operations } & \multicolumn{2}{|c|}{ Wet beneficiation } & \multirow[t]{2}{*}{ Total } \\
\hline & & Direct impact & Total impact & Direct impact & Total impact & \\
\hline Water depletion & $\mathrm{m}^{3}$ & - & $2.51 \mathrm{E}-01$ & $1.20 \mathrm{E}-02$ & $7.12 \mathrm{E}-01$ & $9.63 \mathrm{E}-01$ \\
\hline Climate change & $\mathrm{kg} \mathrm{CO}_{2} \mathrm{eq}$ & $5.96 \mathrm{E}-02$ & $1.81 \mathrm{E}-01$ & - & 1.94E-01 & $3.75 \mathrm{E}-01$ \\
\hline Photochemical oxidant formation & $\mathrm{kg}$ NMVOCs & $2.41 \mathrm{E}-01$ & $2.42 \mathrm{E}-01$ & - & $7.50 \mathrm{E}-04$ & $2.43 \mathrm{E}-01$ \\
\hline Human toxicity & $\mathrm{kg} 1,4 \mathrm{DB}$ eq & $6.20 \mathrm{E}-02$ & $1.08 \mathrm{E}-01$ & $1.50 \mathrm{E}-02$ & $1.39 \mathrm{E}-01$ & $2.47 \mathrm{E}-01$ \\
\hline Terrestrial acidification & $\mathrm{kg} \mathrm{SO}_{2} \mathrm{eq}$ & $1.35 \mathrm{E}-01$ & $1.36 \mathrm{E}-01$ & - & $7.00 \mathrm{E}-04$ & $1.37 \mathrm{E}-01$ \\
\hline PM10 & $\mathrm{kg}$ PM10 eq & 7.10E-02 & 7.12E-02 & - & $5.20 \mathrm{E}-04$ & $7.18 \mathrm{E}-02$ \\
\hline Ionizing radiation & $\mathrm{kg}{ }^{235} \mathrm{U}$ & $6.45 \mathrm{E}-03$ & $1.75 \mathrm{E}-02$ & - & $7.41 \mathrm{E}-03$ & $2.49 \mathrm{E}-02$ \\
\hline Agri land occupation & $\mathrm{m}^{2} /$ year & - & $2.75 \mathrm{E}-03$ & - & $4.20 \mathrm{E}-03$ & $6.95 \mathrm{E}-03$ \\
\hline Freshwater ecotoxicity & $\mathrm{kg} 1,4 \mathrm{DB}$ eq & - & $9.40 \mathrm{E}-04$ & $9.21 \mathrm{E}-05$ & $4.28 \mathrm{E}-03$ & $5.22 \mathrm{E}-03$ \\
\hline Terrestrial ecotoxicity & $\mathrm{kg} 1,4 \mathrm{DB}$ eq & $1.65 \mathrm{E}-05$ & $6.28 \mathrm{E}-05$ & $1.78 \mathrm{E}-03$ & $1.81 \mathrm{E}-03$ & $1.84 \mathrm{E}-03$ \\
\hline Freshwater eutrophication & $\mathrm{kg} \mathrm{P}_{\text {eq }}$ & - & $1.97 \mathrm{E}-05$ & 5.37E-05 & $1.30 \mathrm{E}-04$ & $1.50 \mathrm{E}-04$ \\
\hline Natural land transformation & $\mathrm{m}^{2}$ & - & 5.57E-05 & - & $2.05 \mathrm{E}-05$ & $7.62 \mathrm{E}-05$ \\
\hline
\end{tabular}


Environmental impact contribution degree of each Life stage

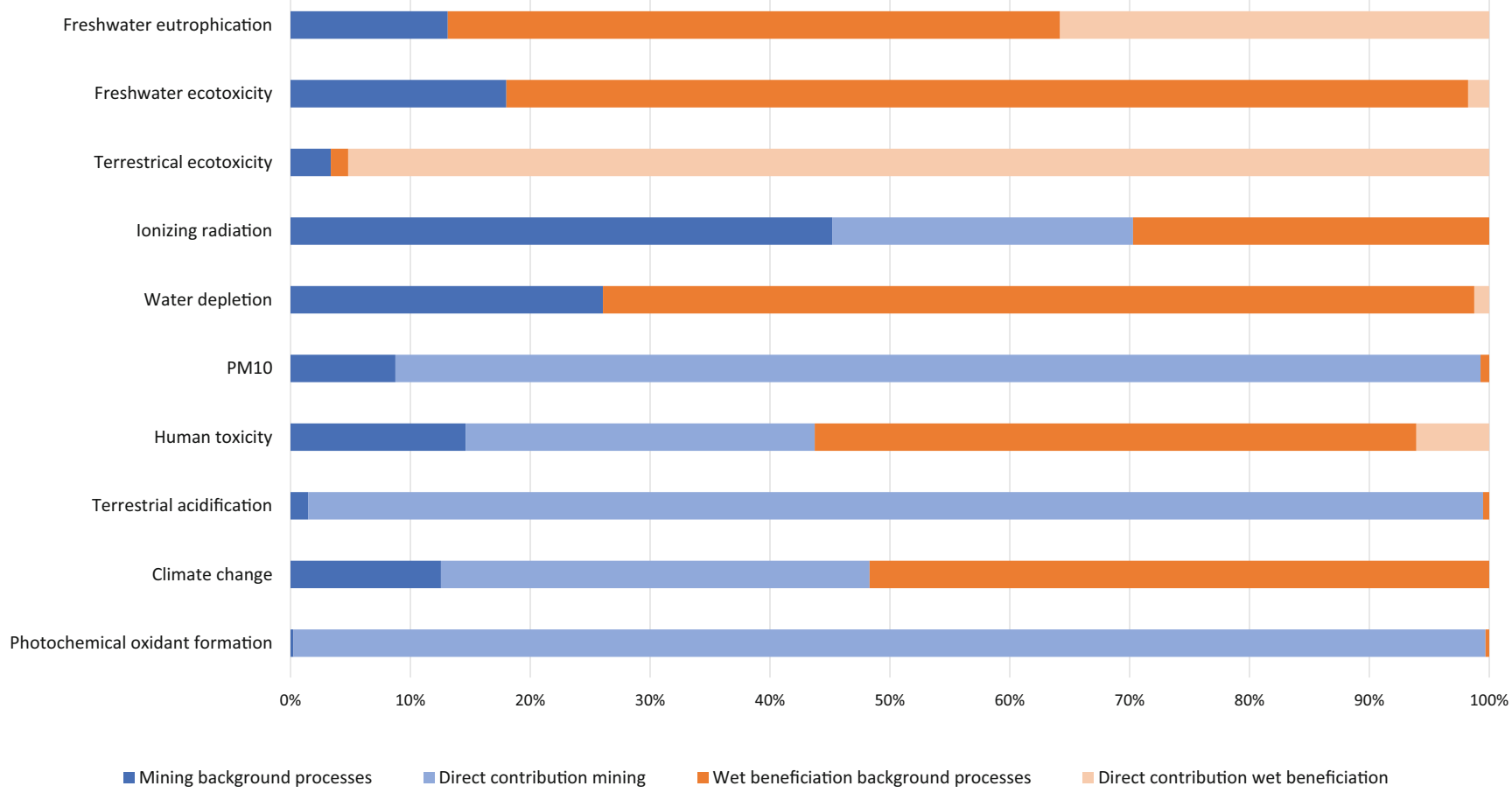

Fig. 4 Contribution analysis of the mining operations and wet beneficiation in different environmental impact categories

water recycling capacity is different. In Tunisia, the company recycles $51-55 \%$ of the total water use. In Florida, the average recycling of water is $95.6 \%$ (Primas et al. 2007).

This study shows some areas of improvement for the beneficiated phosphate rock production in Tunisia. For instance, during mining operations, two areas can be improved; (1) dust control measures need to be implemented for blasting, transport and mechanical preparation, (2) improve the energy efficiency of the process and transport as alternative transport structure exist already such as rail and conveyor. During the wet beneficiation process, two areas can be improved; (1) increase the water recyclability and (2) improve the management of beneficiation waste during the transfer of the slurry to the pond and settling and dewatering in the pond.

Improvement area for phosphate rock mining and beneficiation in general are (1) water use, especially for countries with arid climate and waterstress conditions, (2) phosphate resource efficiency as the lossess of phosphorus between mining and beneficiation are high, and (3) natural land modification as the topography, the quality and the functionality of large surfaces of natural land are altered during mining operations.

\subsection{Model validation}

For the evaluation and discussion of the results achieved in this work, the results were compared with the product system of beneficiated phosphate rock in Florida/USA from the Ecoinvent database using the same LCIA method (ReCiPe, Midpoint (H)).

The Ecoinvent database uses the LCA study conducted by (Primas et al. 2007). The two investigated product systems have comparable process steps and technologies (see Table 3).

Table 3 Characteristic of beneficiated phosphate rock production in Tunisia and the USA

\begin{tabular}{lll}
\hline & USA (Florida) & Tunisia \\
\hline Final product & Wet beneficiated phosphate rock at 29\% & Wet beneficiated phosphate rock at 29\% \\
Mining operations & Open pit & Open pit \\
Strip ratio (Moved soil: beneficiated PR) & $11: 1$ & $23: 1$ \\
Resource in ground & Phosphorus 18\% in apatite, 4\% in cure ore in- & Phosphorus 18\% in apatite, 11\% in cure ore in- \\
& ground & ground \\
Beneficiation & Washing with water + flotation & Washing with water \\
\hline
\end{tabular}




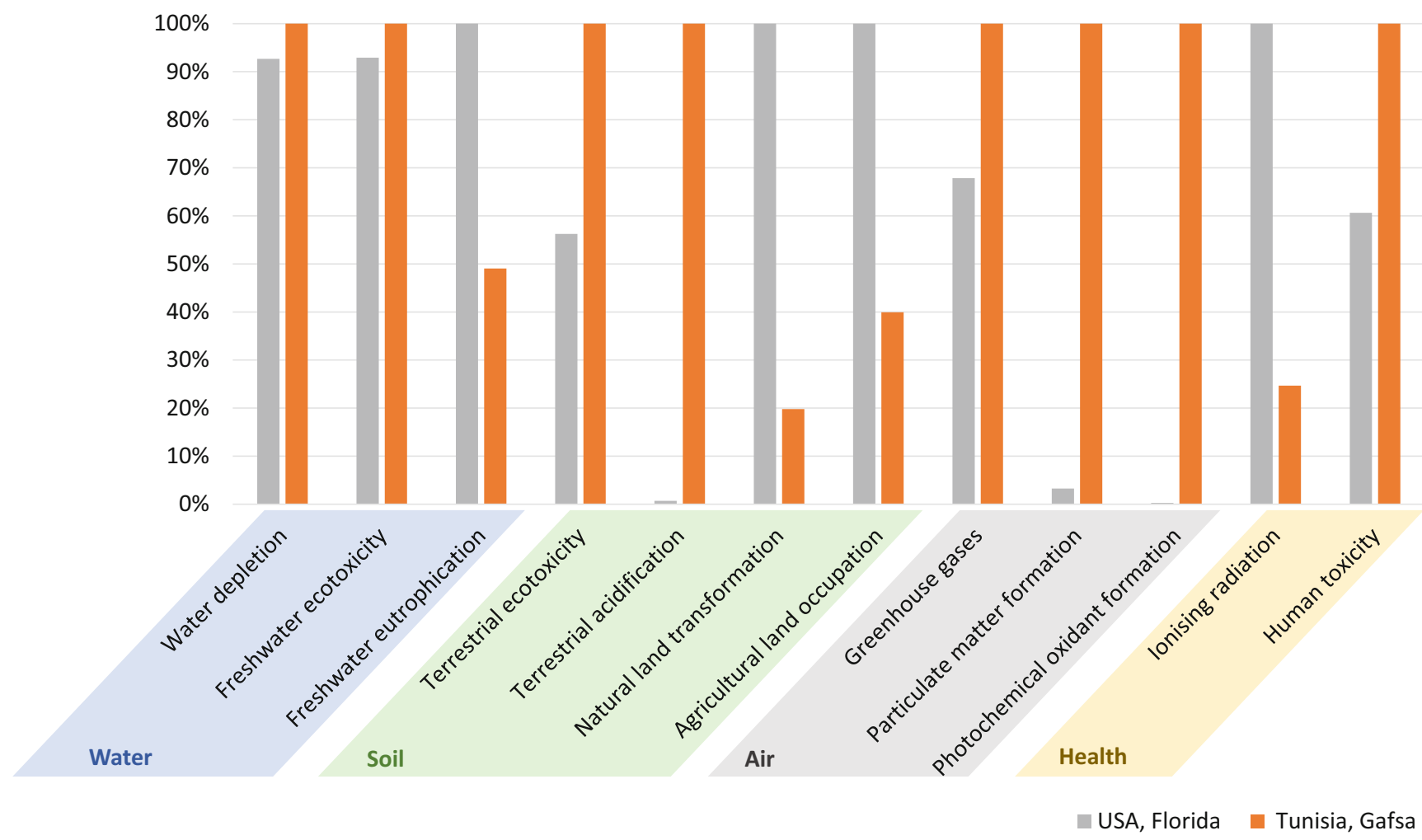

Fig. 5 Comparison of the environmental impacts of two product systems of wet beneficiated phosphate rock in Tunisia and the USA-Relative indicator results of the respective product systems. For each indicator, the maximum result is set to $100 \%$, and the results of the other variant are displayed in relation to this result

In comparison to the production system in Florida, the production of $1 \mathrm{~kg} \mathrm{P}_{2} \mathrm{O}_{5}$ in Tunisia has higher environmental impacts in eight impact categories out of twelve (see Fig. 5):

For the Endpoint area of protection "water", the wet beneficiation in Tunisia has 7\% higher impact on water depletion and water ecotoxicity, as the pumped well water per $\mathrm{kg}$ beneficiated phosphate rock is $0.0034 \mathrm{~m}^{3}\left(0.0117 \mathrm{~m}^{3}\right.$ per $\mathrm{kg}$ $\mathrm{P}_{2} \mathrm{O}_{5}$ ). For the product system in Florida, the average recycling of water is $95.6 \%$. The average pumped water needed per $\mathrm{kg}$ beneficiated phosphate rock is $0.0029 \mathrm{~m}^{3}\left(0.01 \mathrm{~m}^{3}\right.$ per $\mathrm{kg} \mathrm{P}_{2} \mathrm{O}_{5}$ ) (Primas et al. 2007).

For the Endpoint area of protection "soil", the wet beneficiation in Tunisia generates $44 \%$ more soil ecotoxicity than in Florida. The surrounding lands are contaminated due to the infiltration of fluorine, sulfate, and nitrate, and heavy metals such as cadmium $\left(7.12 \mathrm{mg}\right.$ of $\mathrm{Cd}$ per $\mathrm{kg} \mathrm{P}_{2} \mathrm{O}_{5}$ ) from settling ponds. For soil acidification, the product system in Florida has almost no impact; however, in Tunisia, the soil acidification is $1.37 \mathrm{E}-01 \mathrm{~kg} \mathrm{SO}_{2}$ eq per $\mathrm{kg} \mathrm{P}_{2} \mathrm{O}_{5}$. due to the gaseous blasting emissions of sulfur oxides SOx and nitrogen oxides NOx.

Regarding natural land modification, for the product system in Tunisia, the assigned flow is "Transformation, to mineral extraction site, from desert" and "Transformation back to mineral extraction site" after the reclamation of the mining area, which results in an $80 \%$ lower impact on natural land transformation than the mining in Florida (transformation from forest and pasture and meadow). Land system change is considered one of the nine planetary boundaries. As reported by the Stockholm Resilience Centre, the land system needs to reflect not only the absolute quantity of land but also its function, quality, and spatial distribution (Stockholm Resilience Centre 2021). The desert ecosystem is a natural system with specific characteristics that changing its landscape can create negative impacts such as, changing the geological and topographical properties of the area.

In Ecoinvent, the impact assessment for this category could not integrate the landscape's transformation after blasting and moving between 30 to $60 \mathrm{~m}$ hight of soil to access phosphate layers. The mining operations in Tunisia inflict a profound transformation of the landscape by displacing huge quantities of overburden and intermediate layers and stockpiled in an area of $0.6 \mathrm{~km}^{2}$ per year. After the mining site's closure, the site is left without rehabilitation as it is considered future phosphate reserves, considering the fraction of phosphate rock lost during the process. Salhi (2017) has reported a desertification problem due to the regression of the vegetation coverage zones of open-pit mining extensions, risk of a landslide of the 
Table 4 Final energy consumption of the wet beneficiated phosphate rock production in Florida/USA and Gafsa/Tunisia

\begin{tabular}{|c|c|c|c|c|c|c|c|}
\hline \multirow[t]{2}{*}{ Energy } & \multirow[t]{2}{*}{ Unit } & \multicolumn{2}{|c|}{ Mining operations } & \multicolumn{2}{|c|}{ Wet beneficiation } & \multicolumn{2}{|l|}{ Total process } \\
\hline & & USA (Florida) $^{\mathrm{a}}$ & Tunisia (Gafsa) & USA (Florida) & Tunisia (Gafsa) & USA (Florida) & Tunisia (Gafsa) \\
\hline Fuel & $M J$ & 0.19 & 0.73 & $0.42^{b}$ & 0.01 & 0.61 & 0.74 \\
\hline \multirow[t]{2}{*}{ Electricity } & $\mathrm{kWh}$ & $1.06 \mathrm{E}-01$ & $6.89 \mathrm{E}-04$ & $1.72 \mathrm{E}-01$ & $3.90 \mathrm{E}-02$ & $2.78 \mathrm{E}-01$ & $3.97 \mathrm{E}-02$ \\
\hline & $M J^{c}$ & $3.82 \mathrm{E}-01$ & $2.48 \mathrm{E}-03$ & $6.19 \mathrm{E}-01$ & $1.40 \mathrm{E}-01$ & $1.00 \mathrm{E}+00$ & $1.43 \mathrm{E}-01$ \\
\hline Total energy & $M J$ & $5.72 E-01$ & $7.27 E-01$ & $1.04 E+00$ & $1.53 E-01$ & $1.61 E+00$ & $8.80 E-01$ \\
\hline
\end{tabular}

${ }^{a}$ Data for Florida are taken from the Ecoinvent Report n ${ }^{\circ} 8$ page 516 (Althaus et al. 2007), the study of Primas et al. (2007) (Primas et al. 2007)

${ }^{b}$ Consumption of Light Fuel Oil LFO for flotation $0.0103 \mathrm{~kg}$ per $\mathrm{kg} \mathrm{P}_{2} \mathrm{O}_{5}$. The conversion factor is $41.2 \mathrm{MJ}$ per kg LFO. Data from Primas et al. (2007) (Primas et al. 2007)

${ }^{\mathrm{c} C o n v e r s i o n}$ factor from $\mathrm{kWh}$ to $\mathrm{MJ}$ is 3.6

massive amount of the overburden piles, and the change of the soil morphology and characteristics leading to a disturbance of the soil structure by uplifting non-fertile layers (the overburden) (Salhi 2017). In the Ecoinvent, it was not possible to assess the physical change of soil and landscape. Only the transformation from one ecosystem to another is considered (for example from forest to mineral extraction, and back from mineral extraction to a forest). In the case of Tunisia, the transformation back to the mineral extraction site does not mean that there are no modifications of the original landscape and impacts on the soil ecosystem.

For the Endpoint area of protection "human health", the same as the terrestrial acidification, Nitrogen Oxides NOx and Carbon Monoxide $\mathrm{CO}$ gases emissions during blasting operation lead to increased Ozone formation (photochemical oxidant), which has a hazardous effect on human health. The Ozone formation potential in Florida is minimal as blasting is not part of their mining process. Moreover the transportation of crude phosphate rock with truck on an unpaved road and the dry mechanical preparation of phosphate rock (crushing, screening, and sieving) contribute to the emission of PM to air, while in Florida, a conveyor is used for the transport and a wet mechanical preparation is conducted without releasing a significant quantity of PM into the air.

The product system in Florida has $75 \%$ higher ionizing radiation potential. For mining operations in both product systems, the radioactivity was calculated the same way (multiplication of Total Particulate Matter TPM by the rock's specific radioactivity). The specific radioactivity of the phosphate rock in Flordia is higher $\left(1700 \mathrm{~Bq}\right.$ for ${ }^{238} \mathrm{U}$ and ${ }^{226} \mathrm{R}$ ) (Azouazi et al. 2001), and the specific radioactivity of phosphate rock in Tunisia is $401.4 \mathrm{~Bq}{ }^{238} \mathrm{U}$ and $325.4 \mathrm{~Bq}$ for ${ }^{226} \mathrm{R}$ (Fattah 2005; Khelifi 2012). However, the emission of TPM is higher in Tunisia $(6.58 \mathrm{E}-03 \mathrm{~kg} / \mathrm{kg}$ crude phosphate rock and 1.00E-03 in Flordia). As a result, the emitted quantity per $\mathrm{kg} \mathrm{P}_{2} \mathrm{O}_{5}$ is higher in Tunisia.

Nevertheless, in the Ecoinvent database, the radioactive decay activity and their decay products (the decay chain of Uranium ${ }^{238} \mathrm{U}$ and $\mathrm{Th}$ releases ionizing radiation) was included but not for this inventory. It explains the high value of ionizing radiation in Florida in comparison to Tunisia. The decay products such as ${ }^{234} \mathrm{U},{ }^{210} \mathrm{~Pb}$, and ${ }^{210} \mathrm{Po}$ were not available in the used data. Therefore, the ionizing radiation potential of Tunisian phosphate rock has high uncertainty.

For human toxicity, the product system in Tunisia has $40 \%$ higher potential of human toxicity. It is related to the higher content of cadmium ( $8 \mathrm{ppm}$ in the beneficiated phosphate rock from Florida vs. $35 \mathrm{ppm}$ in the beneficiated phosphate rock from Tunisia) released in the dust during mining operations, and in the slurry out of the beneficiation plant.

Although the production of $1 \mathrm{~kg} \mathrm{P}_{2} \mathrm{O}_{5}$ in Tunisia consumes less energy than in Florida, Tunisia's product system has a 32\% higher Global warming potential (GWP) than Florida. According to the Ecoinvent report, the final energy demand in Flordia is $1.61 \mathrm{MJ}$ due to high electricity consumption during the beneficiation process in addition to the consumption of light fuel oil for the flotation (see). The final energy demand in Tunisia is $8.81 \mathrm{E}-01 \mathrm{MJ}$, with $83 \%$ of the energy is diesel burned in machinery during the mining operations (7.25E-01 MJ) (see Table 4).

A higher GWP in Tunisian production conditions can be explained by high consumption of diesel and the use of nitrate explosive during mining operations; Diesel burned contributes $18.2 \%$ to climate change, blasting contributes $15.4 \%$ to climate change, and transport with truck contributes $4.2 \%$ to climate change. Moreover, the background process "market of wastewater treatment facility" contributes $43 \%$ to climate change, while in Florida, electric power is used for material handling and conveyor transport of crude phosphate rock ( $72 \%$ contribution to climate change).

\section{Conclusion}

The use of primary data improves our knowledge about open pit mining of phosphate rock and phosphate wet beneficiation in similar climatic conditions to Tunisia as phosphate rock reserves are mainly concentrated in North Africa and the Middle East. 
This study had contributed to reduce the research gap of incomplete reporting information, environmental externalities of phosphate mining, and the access to data to one of the major global producer of beneficiated phosphate rock.

It also shows comparable results to the generic LCI of beneficiated phosphate rock in the Ecoinvent database for USA. This study contributes to enlarge data about sedimentary phosphate rock mining in the world as actually only the USA and Morocco were reported in databases.

The comparison with data for the USA Florida beneficiated phosphate rock from the Ecoinvent database shows that the environmental impact varies according to the mining operations and the beneficiation process. It depends on the use or not of explosives during the extraction, the mechanical preparation (dry or wet), and the mining operations and transportation's energy efficiency. Moreover, the resource efficiency depends on the technology used during the beneficiation especially for water dewatering and recycling, and the recovery of fine phosphate particles from the slurry and the slurry management when exiting the beneficiation plant.

Finally, this study also add recommendation to update the list of elementary flow as well as the update of the impact category: Land transformation in Ecoinvent database concerning desert ecosystem and the impacts of altering its landscape.

Supplementary Information The online version of this article (https:// doi.org/10.1007/s00550-021-00522-8) contains supplementary material, which is available to authorized users.

Funding This research as part of the Ph.D was funded by the DAAD.

Author Contribution Conceptualization: [Roukaya Issaoui]; Methodology: [Tobias Viere], verification of the approach; Formal analysis and investigation: [Roukaya Issaoui], Data collection, calculation and modeling; Writing — original draft preparation: [Roukaya Issaoui, Christine Rösch, Jörg Woidasky]; Writing — review and editing: [Roukaya Issaoui, Christine Rösch, Jörg Woidasky]; Funding acquisition: [Jörg Woidasky, Mario Schmidt, Christine Rösch]; Resources: [Mario Schmidt, Christine Rösch], softwares and databases access; Supervision: [Tobias Viere, Mario Schmidt]

Funding Open Access funding enabled and organized by Projekt DEAL.

\section{Declarations}

Conflict of interest R. Issaoui, C. Rösch, J. Woidasky, M. Schmidt and $\mathrm{T}$. Viere declare that they have no competing interests.

Ethical standards This chapter does not contain any studies with human participants or animals performed by any of the authors. Consent to participate: The consent of participation of the company is included in a separate document submitted with the manuscript. Consent for publication: Not applicable.

Open Access This article is licensed under a Creative Commons Attribution 4.0 International License, which permits use, sharing, adaptation, distribution and reproduction in any medium or format, as long as you give appropriate credit to the original author(s) and the source, pro- vide a link to the Creative Commons licence, and indicate if changes were made. The images or other third party material in this article are included in the article's Creative Commons licence, unless indicated otherwise in a credit line to the material. If material is not included in the article's Creative Commons licence and your intended use is not permitted by statutory regulation or exceeds the permitted use, you will need to obtain permission directly from the copyright holder. To view a copy of this licence, visit http://creativecommons.org/licenses/by/4. $0 \%$.

\section{References}

Althaus H-J, Hischier R, Osses M, Primas A, Hellweg S, Jungbluth N, Chudacoff M (2007) Life cycle inventories of chemicals. Edited by Swiss center for life cycle inventories. EMPA; ETH; ESU-services (Ecoinvent report No. 8, V.2).

Azouazi M, Ouahidi Y, Fakhi S, Andres Y, Abbe JC, Benmansour M (2001) Natural radioactivity in phosphates, phosphogypsum and natural waters in Morocco. J Environ Radioact 54(2):231-242. https://doi.org/10.1016/S0265-931X(00)00153-3

Bronzo Perasso-carrière et bétons (2018): Demande d'autorisation environnementale unique pour l'exploitation d'une installation classe pour la protection de l'environnement, Renouvellement de l'autorisation d'exploiter avec extension de la carrière de sainteMarthe: Pièce 5-Demande d'autorisation les effets sur la santé. Application for a single environmental permit for the operation of an installation classed for environmental protection, Renewal of the authorization to operate with extension of the quarry of Sainte-Marthe: Exhibit 5-Application for authorization health effects. Edited by Bronzo Perasso-carrière et bétons, checked on $2 / 22 / 2020$

Charni Majoubi H, Abbes A, Aboudi A, Khayati S, Grauby A, Gharbi HA, Mtimet S (1991) Étude de la radioactivité naturelle dans le sol du sud tunisien Région de Gafsa Tozeur. Radioprotection 26(3):537-549. https://doi.org/10.1051/radiopro/1991019

Direction of Accounting (2017) Tableau de bord de gestion et des indicateurs de performance de 2016: les coût complets. File number 6. Internal document

Direction of Accounting (2018) Tableau de bord de gestion. File number 7. Internal document

Environmental Protection Agency (1998) AP-42 11.9 western surface coal mining. Revision of emission factors for AP-42 section 11.9 western surface coal mining

EU Ad-Hoc Working Group on Raw Materials (2014) Report on critical raw materials for the EU (Edited by European Commission, checked on 9/20/2019)

European Commission (2017) Conflict minerals regulation explained. https://ec.europa.eu/trade/policy/in-focus/conflict-minerals-regu lation/regulation-explained/. Accessed 30 Sept 2019

European Commission (2020b): Communication from the comimission to the European Parliament, the council, the European Economic and Social Committee and the Committee of the regions: Critical Raw Materials resilience: Charting a Path towards greater Security and Sustainability. Brussels (COM(2020) 474). Available online at https://ec.europa.eu/docsroom/documents/42849, checked on 11/20/2020.

European Commission (2010) Critical raw materials for the EU. Report of the Ad-hoc Working Group on defining critical raw materials. European Commission (Ref. Ares(2014)2187691-02/07/2014), checked on 9/19/2019.. European Commission, European Commission

European Commission (2020a) Commission annouces actions to make Europe's raw materials supply more secure and sustainable. European Commission. Brussels (IP/20/1542) 
European Commission (2020c) Critical raw materials for strategic technologies and sectors in the EU: a foresight study. European Commission, Luxembourg

European Environmental Agency (2019a) 2.A.5.a Quarrying and mining calculation model 2019-Spreadsheet-European Environment Agency. https://www.eea.europa.eu/publications/emep-eeaguidebook-2019/part-b-sectoral-guidance-chapters/2-industrialprocesses/2-a-mineral-products/2-a-5-a-quarrying-1/view. Accessed 3 July 2020

European Environmental Agency (Ed.) (2019b): 2.A.5.a Quarrying and mining of minerals other than coal. Technical guidance to prepare national emission inventories. With assistance of Nathan Vandromme, Nadia Taïeb, Julien Viencent, Nadine Allemand. European Environmental Agency (EEA) (EMEP/EEA air pollution emission inventory guidbook, 2019). Available online at https:// www.eea.europa.eu/publications/emep-eea-guidebook-2019/ part-b-sectoral-guidance-chapters/2-industrial-processes/2-amineral-products/2-a-5-a-quarrying/view, checked on 3/3/2020.

Fattah N (2005) Geological structure of phosphorites in the Gafsa basin (Tunisia) and their geochemical specialization. Dissertation. The Russian State Geological Prospecting University (MGRI-RSGPU), Moscow. https://www.dissercat.com/content/ geologicheskoe-stroenie-fosforitov-basseina-gafsa-tunis-i-ikhgeokhimicheskaya-spetsializats. Accessed 20 Jan 2020

Goedkoop, Mark; Heijungs, Reinout; Huijbregts, Mark; Schryver, An de; Struijs, Jaap; Van Zelm, Rosalie (2009): ReCiPe 2008 : A life cycle impact assessment method which comprises harmonised category indicators at midpoint and the endpoint level. Report 1: Characterisation. Edited by Ministry of Housing, Spatical Planning and Environment (VROM), checked on 3/4/2020.

Jasinski SM, Lindsay C (2001) Marketable phosphate rock in crop year 2001. USGS national minerals information center (minerals industry surveys). https://s3-us-west-2.amazonaws.com/prdwret/assets/palladium/production/mineral-pubs/phosphate-rock/ prcyr01.pdf. Accessed 14 Jan 2021

Khelifi L (2012) Contribution à l'étude géochimique des phosphates du bassin de Gafsa-Métlaoui : Exemple du Gisement d'Oum EL Khecheb. Master. FACULTE DES SCIENCES DE TUNIS, Tunis. INRAP. https://inis.iaea.org/collection/NCLCollectionStore/_ Public/46/051/46051968.pdf. Accessed 30 Sept 2019

Mining planification direction (2018): Measured and demonstrated reserves in Gafsa mining region. File number 2. Internal document.

Nedelciu C-E, Ragnarsdóttir KV, Stjernquist I, Schellens MK (2019) Opening access to the black box: the need for reporting on the global phosphorus supply chain. Ambio. https://doi.org/10.1007/ s13280-019-01240-8

Organisme Professionnel de Prévention du Bâtiment et des Travaux Public (2003) Les principaux explosifs utilisés dans les travaux publics. the main explosives used in public works

PRé Sustainability (2020) ReCiPe. https://www.pre-sustainability. com/recipe. Accessed 9 Apr 2020

Primas A, Capello C, Hischier R (2007) Phosphate rock. In: Swiss Center for Life Cycle Inventories (ed) Life cycle inventories of chemicals. EMPA; ETH; ESU-services (Ecoinvent report No. 8, V.2), vol 2, pp 508-529

Salhi B (2017) Mutations socio-spatiales et environnementales du bassin minier de Gafsa (Sud-ouest de Tunisie): Approche par les outils géomatiques. Dissertation. Université Bretagne Loire, Bretagne France. Le Mans Université,

Smida, Olfa (2012): Etude du comportement des rejets de l'industrie phosphatière du bassin de Gafsa-Metlaoui (M'dhilla, R'deyef, Moularès) dans les conditions de surface. Study of the behaviour of discharges from the phosphate industry in the Gafsa-Metlaoui basin (M'dhilla, R'deyef, Moularès) under surface conditions. Faculté des sciences de Tunis, Sidi Thabet. Institut National de Recherche et d'Analyse Physico-chimique (INRAP), checked on $1 / 29 / 2020$

Stockholm Resilience Centre (2021) The nine planetary boundaries

Tartakovsky D, Stern E, Broday DM (2016) Indirect estimation of emission factors for phosphate surface mining using air dispersion modeling. Sci Total Environ 556:179-188. https://doi.org/ 10.1016/j.scitotenv.2016.02.207

USGS National Minerals Information Center (2019) Mineral Commodity Summaries 2018-Phosphate rock. Edited by U.S. Geological Survey. USGS National Minerals Information Center. https://prd-wret.s3-us-west-2.amazonaws.com/assets/palladium/ production/atoms/files/mcs2019 all.pdf. Accessed 10 July 2019

Van Kauwenbergh SJ (2010) World phosphate rock reserves and resources (Edited by International Fertilizer Development Center (IFDC), )

Weatherspark (2020) Météo habituelle à Metlaoui, Gafsa TunisieWeather Spark. Weather at Metlaoui, Gafsa, Tunisia-Weather Spark. https://fr.weatherspark.com/y/58621/M\%C3\%A9t\%C3 \%A9o-habituelle-\%C3\%A0-Metlaoui-Tunisie. Accessed 22 June 2020 